\title{
LETTER TO THE EDITOR
}

\section{Does increasing the JAK2V617F assay sensitivity allow to identify more patients with MPN?}

Blood Cancer Journal (2012) 2, e70; doi:10.1038/bcj.2012.15; published online 4 May 2012

The detection of the JAK2V617F mutation has become an essential tool in BCR-ABL1-negative myeloproliferative neoplasms (MPNs) diagnosis, as it is present in $95 \%$ of polycythemia vera (PV) patients and $60 \%$ of essential thrombocytemia (ET) or myelofibrosis patients. ${ }^{1}$ JAK2V617F-positive MPNs are different from other hematological malignant disease in that, although the JAK2V617F mutation is considered as the causative origin of the disease, the tumor burden at the time of diagnosis as assessed by the \% of JAK2V617F alleles in peripheral blood or bone marrow can vary from $100 \%$ to very low levels with no correlation to blood cell counts. It is still undefined which lowest level might be detected to allow the diagnosis of every MPN patients. Using the Mustascreen kit (Ipsogen, Marseilles, France), the detection limit of which was close to $2 \%$, most of the patients were easily classified as positive or negative. However, some rare patients were considered as doubtful because the level of fluorescence detected from the mutant probe was between the negative control and the $2 \%$ reference positive kit control. Recently, we decided to move toward a more sensitive method, the Mutaquant kit (Ipsogen), characterized by a detection limit close to $0.1 \%$. DNA was extracted from whole blood using the QIA-AMP DNA blood mini kit (Qiagen, Hilden, Germany). In the few months after we adopted a more sensitive method, we identified positive patients among patients previously tested negative. These results raised two questions: who are the patients with very low levels of JAK2V617F mutation and consequently what level of sensitivity a method should have in a routine diagnosis setting. All patients included have given informed consent for this study, which has been approved by the local ethics committee.

To assess the specificity of the Mutaquant method, 49 samples taken from blood donors were tested and no sample was detected as positive using a cut-off of $0.1 \%$. Next, we diluted one $100 \%$ mutated patient DNA sample in a negative one. The $10^{-2}$ and $10^{-3}$ dilutions were measured at $1.2 \%$ and $0.1 \%$, respectively, whereas the $10^{-4}$ dilution was found negative. These results confirmed the lower detection limit of this method to be $0.1 \%$ mutant allele burden.

Within 6 months after introducing Mutaquant in a routine setting, we prospectively investigated 688 patients. Overall, 497 were tested for the first time, whereas 191 had already been analyzed previously using Mutascreen method. In 98 cases, the previous sample was positive and the Mutaquant result confirmed the positivity. In 93 cases, the previous result was negative, but in 7 of them the Mutaquant method detected a low level of JAK2V617F mutant allele (Table 1). When reanalyzed using the novel method, a low level of positivity was also detected on a frozen aliquot of the previous sample for these seven patients. In three cases several DNA samples were available, which were all found positive with Mutaquant, even samples taken as far as 5 years before, with a constant level of positivity throughout time. Of these seven patients, three were suspected of having ET, one presented with an isolated elevated hematocrit and one with a myelofibrosis. Patient 6 presented with a high WBC count, normal

\begin{tabular}{|c|c|c|c|c|c|c|c|c|c|c|c|c|}
\hline Patient & $\begin{array}{l}\text { Age } \\
\text { (years) }\end{array}$ & Sex & $\begin{array}{l}\text { Date of } \\
\text { sampling }\end{array}$ & $\begin{array}{l}\text { Mutaquant } \\
\text { (\%) }\end{array}$ & Mutascreen & Diagnosis & $\begin{array}{c}\text { Cytoreductive } \\
\text { treatment }\end{array}$ & $\begin{array}{l}\text { HTC } \\
(\%)\end{array}$ & $\begin{array}{c}H b \\
(g / d l)\end{array}$ & $\begin{array}{l}W B C \\
(G / l)\end{array}$ & $\begin{array}{l}P L T \\
(G / l)\end{array}$ & $\begin{array}{l}\text { Additional } \\
\text { mutations }\end{array}$ \\
\hline$\# 1$ & 49 & $\mathrm{~F}$ & $\begin{array}{l}2008 \\
2009 \\
2011\end{array}$ & $\begin{array}{l}0.30 \\
0.50 \\
0.60\end{array}$ & $\begin{array}{l}\mathrm{Neg} \\
\mathrm{Neg} \\
\mathrm{ND}\end{array}$ & ET & $\mathrm{HU}$ & NA & NA & NA & 720 & MPL neg \\
\hline \#2 & 49 & M & $\begin{array}{l}2007 \\
2011\end{array}$ & $\begin{array}{l}0.90 \\
0.70\end{array}$ & $\begin{array}{l}\mathrm{Neg} \\
\text { ND }\end{array}$ & Thrombosis & None & 47.4 & 17.1 & 7.7 & 335 & MPL neg \\
\hline \#3 & 47 & M & $\begin{array}{l}2006 \\
2010 \\
2011\end{array}$ & $\begin{array}{l}1.00 \\
1.00 \\
0.90\end{array}$ & $\begin{array}{l}\mathrm{Neg} \\
\mathrm{Neg} \\
\mathrm{ND}\end{array}$ & ET & None & 42 & 12.9 & 5.6 & 600 & MPL neg \\
\hline$\# 4$ & 49 & M & $\begin{array}{l}2010 \\
2011\end{array}$ & $\begin{array}{l}0.10 \\
0.20\end{array}$ & $\begin{array}{l}\mathrm{Neg} \\
\mathrm{ND}\end{array}$ & PV & None & 54 & 18.1 & 7.5 & 189 & Exon 12 neg \\
\hline \#5 & 56 & $\mathrm{~F}$ & $\begin{array}{l}2007 \\
2010 \\
2011\end{array}$ & $\begin{array}{l}0.20 \\
0.20 \\
0.20\end{array}$ & $\begin{array}{l}\mathrm{Neg} \\
\mathrm{Neg} \\
\mathrm{ND}\end{array}$ & ET & $\mathrm{HU}$ & 39.5 & 12.8 & 6.5 & 340 & MPL neg \\
\hline \#6 & 72 & $\mathrm{~F}$ & $\begin{array}{l}2010 \\
2011\end{array}$ & $\begin{array}{l}0.60 \\
0.50\end{array}$ & $\begin{array}{l}\mathrm{Neg} \\
\text { ND }\end{array}$ & MPN & None & 42.3 & 14.6 & 13.4 & 134 & MPL neg \\
\hline \#7 & 71 & $\mathrm{~F}$ & $\begin{array}{l}2010 \\
2011\end{array}$ & $\begin{array}{l}0.20 \\
0.30\end{array}$ & $\begin{array}{l}\mathrm{Neg} \\
\mathrm{ND}\end{array}$ & Myelofibrosis & None & 30.5 & 10.4 & 5.9 & 100 & MPL neg \\
\hline
\end{tabular}

Abbreviations: ET, essential thrombocytemia; Exon 12, mutation at the exon 12 of the JAK2 gene; F, female; HTC, hematocrit; HU, hydroxyurea; M, male; MPL, mutation at W515 of the MPL gene; NA, not available; ND, not done; Neg, negative; PLT, platelet; Pos, positive; PV, polycythemia vera. 
Table 2. Biological and clinical data of eight patients found with detectable JAK2V617F mutations, although previously tested doubtful

\begin{tabular}{|c|c|c|c|c|c|c|c|c|c|c|}
\hline Patient & Age (years) & Sex & Suspected diagnosis & $\%$ JAK2V617F & Vascular events & Treatment & HTC (\%) & $H b(g / d l)$ & $W B C(G / I)$ & $P L T(G / l)$ \\
\hline$\# 10$ & 81 & $\mathrm{~F}$ & Myelofibrosis & 4.8 & No & None & 27.7 & 9.0 & 9.5 & 24 \\
\hline$\# 11$ & 84 & M & PV & 1.3 & No & None & 55 & 18.5 & 8.7 & 217 \\
\hline \#14 & 61 & M & PV & 1.3 & No & Phlebotomy & 48 & 16.2 & 9.9 & 221 \\
\hline \#16 & 78 & $\mathrm{~F}$ & PV & 2.9 & No & ASA, HU & 60 & 18.3 & 12.1 & 490 \\
\hline \#19 & 63 & $\mathrm{~F}$ & PV & 2.6 & No & None & 50.3 & 17 & 11.3 & 197 \\
\hline \#23 & 65 & M & ET & 2.8 & Yes & ASA, HU & 33.5 & 10.4 & 10.6 & 1200 \\
\hline \#24 & 25 & $\mathrm{~F}$ & ET & 1.1 & Yes & ASA, HU & 36.3 & 12.8 & 4.8 & 238 \\
\hline$\# 25$ & 64 & M & PV & 1.5 & No & ASA & 46.4 & 16.2 & 6.5 & 247 \\
\hline
\end{tabular}

Abbreviations: ASA, aspirin; ET, essential thrombocytemia; HTC, hematocrit; HU, hydroxyurea; NA, not available; PLT, platelet; PV, polycythemia vera. Only data from patients with detectable are presented. In patients with low allele burden of JAK2V617F mutation, JAK2 exon 12 mutations have been tested in patients with PV, whereas MPL515 mutations have been tested in patients with either ET or myelofibrosis

RBC and platelet counts, circulating immature myeloid cells and trisomy 8 in bone marrow cells. A chronic neutrophilic leukemia, a rare entity in which JAK2V617F has been reported, ${ }^{2}$ is unlikely in this case because of immature circulating myeloid cells and the absence of splenomegaly or segmented neutrophils. Patient 7 presented with unexplained repeated pulmonary embolisms without any hematological abnormality and a red cell mass in the normal range, excluding a polycythemia. The impact of the mutation in this patient is still questioning as JAK2V617F in thrombotic syndromes is frequent in splanchnic vein thrombosis ${ }^{3}$, but extremely rare in unprovoked thrombosis. ${ }^{4}$ We analyzed DNA from erythroid colonies from patient 3 and, in line with the DNA from total blood (1\%), we found one JAK2V617F heterozygous colony among 48 tested, confirming the existence of a very low mutant allele burden.

An unsolved question is whether a mutant allele burden of $1 \%$ or less really reflects the tumor burden and whether the patients found with less than $1 \%$ of JAK2V617F allele burden can be classified as MPN patients, as the WHO classification do not require quantitative analysis. ${ }^{5}$ In ET, a restriction of the mutation to the megakaryocytic lineage could lead to underestimation of the mutated cells percentage when analyzing blood DNA. Platelet RNA may be a better material to evaluate the tumor allele burden in some cases. We excluded the presence of an additional mutation in MPL (MPL Mutascreen kit) or the exon 12 of JAK2 (as previously described ${ }^{6}$ ) as driving the phenotype for every patient with less than $1 \%$ allele burden. Some studies reported the presence of extremely low levels $(<0.1 \%)$ of JAK2V617F in healthy people, ${ }^{7,8}$ which may be explained in two ways: either the mutation can be transient or the mutant allele burden can rise from undetectable to detectable levels throughout time and those patients are in a preclinical phase. Among the seven patients identified in our study with low allele burden, five were suspected of MPN because of increased hematocrit or platelet counts or myelofibrosis. The JAK2 mutation confirmed the clonal myeloproliferation and allowed to ascertain the diagnosis of MPN.

We next reanalyzed frozen aliquots from 18 patients declared doubtful with Mutascreen. Using Mutaquant we detected JAK2V617F mutation in eight patients (Table 2), with an allele burden close to $2 \%$. Suspected diagnosis at the time of sampling was myelofibrosis, ET and PV in 1, 2 and 5 patients, respectively. Only patient 25 was questionable as he presented with subnormal hematocrit throughout time, but his son had a JAK2V617F-positive PV.

As a conclusion, our study argues for the choice of a JAK2V617F detection method characterized by a detection limit under $1 \%$ in order to identify more MPN patients. However, using such a method will inevitably lead to the detection of patients with very low allele burden, the diagnosis of which may be questionable although according to the WHO classification the detection of the
JAK2V617F mutation is one of the major criteria leading to MPN diagnosis, ${ }^{5}$ with no indication regarding the allele burden. Careful examination of patient's phenotype is needed before modifying treatment strategy until a large cohort of such patients will allow to decipher upon their outcome.

\section{CONFLICT OF INTEREST}

The authors declare no conflict of interest.

E Kouroupi ${ }^{1}$, J-J Kiladjian ${ }^{2}$, C Dosquet $^{1}$, M-L Menot ${ }^{1}$, N Bonnin ${ }^{1}$ L Ades $^{3}$, W Vainchenker ${ }^{4}, C_{\text {Chomienne }}{ }^{1}$ and B Cassinat ${ }^{1}$ ${ }^{1} A P-H P$, Unite de Biologie Cellulaire, Hopital Saint-Louis,

Paris, France,

${ }^{2} A P-H P$, Centre d'Investigations Cliniques, Hopital Saint-Louis,

Paris, France;

${ }^{3} A P-H P$, Service d'Hematologie Clinique, Hopital Avicenne, Bobigny, France and

${ }^{4}$ Service d'Immunologie et Hematologie, Hopital Saint-Louis, Paris, France

E-mail: bruno.cassinat@sls.aphp.fr

\section{REFERENCES}

1 Barbui T, Barosi G, Birgegard G, Cervantes F, Finazzi G, Griesshammer M et al. Philadelphia-negative classical myeloproliferative neoplasms: critical concepts and management recommandations from European LeukemiaNet. J Clin Oncol 2011; 29: 761-770.

2 Mc Lornan DP, Percy MJ, Jones AV, Cross NC, Mc Mullin MF. Chronic neutrophilic leukemia with an associated V617F JAK2 tyrosine kinase mutation. Haematologica 2005; 90: 1696-1697.

3 Kiladjian JJ, Cervantes F, Leebeek FW, Marzac C, Cassinat B, Chevret S et al. The impact of JAK2 and MPL mutations on diagnosis and prognosis of splanchnic vein thrombosis: a report on 241 cases. Blood 2008; 111: 4922-4929.

4 Ugo V, Le Gal G, Lecucq L, Mottier D, Oger E. EDITH Collaborative Study Group. Prevalence of the JAK2 V617F mutation is low among unselected patients with a first episode of unprovoked venous thromboembolism. J Thrombosis and Haemostasis 2008; 6: 203-205.

5 Tefferi A, Vardiman JW. Classification and diagnosis of myeloproliferative neoplasms: the 2008 World Health Organization criteria and point-of-care diagnostic algorithms. Leukemia 2008 22: 14-22.

6 Ugo V, Tondeur S, Menot ML, Bonnin N, Le Gac G, Tonetti C et al. Interlaboratory development and validation of a HRM method applied to the detection of JAK2 exon 12 mutations in polycythemia vera patients. PLoS One 2010; 5: e8893.

7 Sidon P, El Housni H, Dessars B, Heimann P. The JAK2V617F mutation is detectable at very low level in peripheral blood of healthy donors. Leukemia 2006; 20: 1622.

8 Martinaud C, Brisou P, Mozziconacci MJ.. Is the JAK2(V617F) mutation detectable in healthy volunteers? Am J Hematol 2010; 85: 287-288.

(c) This work is licensed under the Creative Commons AttributionOUMERIIEHIS RESERVED NonCommercial-No Derivative Works 3.0 Unported License. To view a copy of this license, visit http://creativecommons.org/licenses/by-nc-nd/3.0/ 